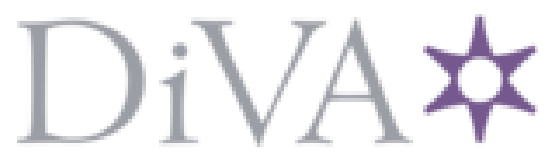

http://www.diva-portal.org

This is the published version of a paper published in Ecology.

Citation for the original published paper (version of record):

Dynesius, M., Hylander, K., Nilsson, C. (2009)

High resilience of bryophyte assemblages in stream-side compared to upland forests.

Ecology, 90: 1042-1054

http://dx.doi.org/10.1890/07-1822.1

Access to the published version may require subscription.

N.B. When citing this work, cite the original published paper.

Permanent link to this version:

http://urn.kb.se/resolve?urn=urn:nbn:se:umu:diva-20912 


\title{
High resilience of bryophyte assemblages in streamside compared to upland forests
}

\author{
Mats Dynesius, ${ }^{1,3}$ Kristoffer Hylander, ${ }^{2}$ and Christer Nilsson $^{1}$ \\ ${ }^{1}$ Landscape Ecology Group, Department of Ecology and Environmental Science, Umeå University, SE-901 87 Umeå, Sweden \\ ${ }^{2}$ Department of Botany, Stockholm University, 10691 Stockholm, Sweden
}

\begin{abstract}
Landscape heterogeneity causes spatial variation in disturbance regimes and resilience. We asked whether the resilience of bryophyte (liverwort and moss) assemblages to clear-cutting differs between streamside and upland boreal forests in northern Sweden. We hypothesized that bryophyte survival and recolonization rates are higher in streamside areas, thus raising resilience. Conversely, disturbance-intolerant but also invading species should be more frequent here, potentially reducing resilience. In each of 18 sites, we compared two 0.1-ha plots (one streamside and one upland) located in old forest that had never been clear-cut with two matching plots in young stands established after clear-cutting of old forests 30-50 years earlier. We used the magnitude of the difference in assemblages between old and young stands as a measure of change and, therefore, resilience (large difference implying low resilience). Species assemblages were more resilient in streamside than in upland forests. Species composition changed significantly in upland but not in streamside forests. Reductions in species richness were more pronounced in upland forests for total richness and for eight subgroups of species. Two results indicated lower survival/recolonization in upland forests: (1) species had a stronger association with old stands in upland areas, and (2) among species present in both the old streamside and old upland plot in a site, fewer appeared in the young upland than in the corresponding streamside plot. Simultaneously, a higher proportion of species invaded streamside areas; 40 of the 262 species encountered in streamside forests increased their occupancy by two or more sites compared to only two of 134 species in uplands. We suggest that in boreal forests spatial variation in resilience of assemblages of forest organisms intolerant of canopy removal is related to factors governed mainly by topography. More generally, we argue that landscape-scale variation in resilience of assemblages is influenced by spatial variation in (1) stress and resource availability, (2) number of disturbanceintolerant species, and (3) magnitude of environmental changes brought about by a disturbance with a specific intensity. We also suggest that rapid recovery in the short term does not necessarily imply higher long-term ability to return to the pre-disturbance state.
\end{abstract}

Key words: boreal forest; bryophyte; colonization; disturbance; extirpation; forestry; liverwort; moss; resilience; resistance; riparian; Sweden.

\section{INTRODUCTION}

Disturbances are integral parts of ecosystems and drive both regional and local heterogeneity (e.g., Sarr and Hibbs 2007). Within landscapes, disturbances vary in intensity, extent, and frequency, and this variation often relates to spatial environmental heterogeneity in a more or less predictable way (White and Jentsch 2001, Turner 2005). The more severe disturbance of hurricanes on the wind-exposed side of mountains is one example (Boose et al. 1994). On the other hand, a disturbance event (e.g., a wildfire) with a given intensity (e.g., total canopy mortality) can show negligible spatial differentiation among landscape elements (Moritz 1997). Ecological responses to relatively uniform disturbances are, however, likely to vary spatially in relation to both

Manuscript received 30 October 2007; revised 27 May 2008; accepted 15 July 2008. Corresponding Editor: J. A. Jones.

${ }^{3}$ E-mail: mats.dynesius@emg.umu.se environmental factors and pre-disturbance species composition. Human disturbances may be useful for studying this variation in response, since they often vary less in intensity across landscapes than do natural disturbances. We used the clear-cutting harvesting system uniformly applied to northern Swedish forests from about 1950 onward to assess differences in resilience of bryophyte assemblages close to small streams and in upland habitats.

In a broad sense, resilience denotes the capacity of a system to cope with disturbance. Ecologists have distinguished between "engineering resilience" and "ecological resilience" that relate to assumptions about single or multiple equilibrium states, respectively (Holling 1973, 1996, Gunderson 2000). Studies of ecological resilience focus on the amount of disturbance a system can absorb without changing into another system, i.e., while still maintaining structures, functions, identity (e.g., species composition) and feedbacks. Engineering resilience, on the other hand, is inversely related to the 
return time of a system to a pre-disturbance state, assuming a single equilibrium. In practice, however, many studies (including this study) addressing the capacity of a system to cope with disturbance apply an "engineering resilience perspective" where pre-disturbance conditions are used as the reference and high resistance to disturbance or high similarity to predisturbance conditions is interpreted as high resilience (e.g., Rydgren et al. 2004). The possibility that a study system can move to another alternative stable state is, however, neither assumed nor denied, but is in many cases difficult to establish because processes are exceedingly slow (as in forest succession; Schröder et al. 2005). According to van Nes and Scheffer (2007), however, a slow rate of return to the original state is indicative of a system that is easier to push into an alternative stable state and they therefore argued that engineering resilience is a good indicator of ecological resilience. Below, the term "resilience" refers to engineering resilience unless otherwise stated.

For some time, ecologists have proposed that resilience is related to resource availability (e.g., Odum and Pinkerton 1955, O’Neill 1976, DeAngelis 1991). Evidence for such a relationship has been provided by, for example, Hamilton and Haeussler (2008), who demonstrated a positive relationship between resource availability and rate of revegetation after slash burning in clear-cuts, and by Myerscough and Clarke (2007), who showed that the vegetation of more productive wet coastal heaths recovered faster after fire than did dry heaths. High resource levels, however, do not necessarily imply high resilience. Arnan et al. (2006) found that resilience of ant communities after fire was higher in dry and low-productivity than in relatively moist and highproductivity Mediterranean vegetation. They attributed this difference to recently burnt areas being more similar to dry than to moist unburned areas. We drew similar conclusions in a study on short-term effects of clearcutting on bryophyte communities in north- and southfacing slopes (Asström et al. 2007). We found that bryophyte communities changed more in south-facing slopes and the underlying process was fewer species losses in north-facing slopes. We attributed these differences to clear-felling causing a smaller absolute change in radiation intensity (and thus surface and air moisture) in north-facing than in south-facing slopes, i.e., clear-cut north-facing slopes are more similar to their forested counterparts for these important environmental factors. These examples show that general trends in resilience along environmental gradients might be difficult to predict since both resource/stress gradients and pre/post-disturbance similarities in environmental factors influence the outcome and these have no general causal relationship. Variation in disturbance intensity along gradients might further complicate the picture (Halpern 1988).

Mosses cover much of the boreal forest floor whereas liverworts are less abundant and are most commonly found on specific substrates such as decomposing wood, tree bases and boulders (Esseen et al. 1997, Frisvoll 1997, Mills and Macdonald 2004). Bryophyte assemblages in boreal forests are at least equally species rich as vascular plants (Berglund and Jonsson 2001, Dynesius and Zinko 2006). Many bryophyte species are intolerant of repeated and long-lasting desiccation, intense solar radiation, and high temperatures (Clausen 1952, Proctor 1990) and bryophyte cover and diversity generally decline after clear-cutting (Newmaster and Bell 2002, Nelson and Halpern 2005, Frego 2007). In boreal streamside forests, clear-cutting almost immediately harms many species, especially liverworts, forest species, and species of convex substrates (e.g., boulders, decomposing wood, and living trees) while favoring others (mosses and species typical of disturbed habitats) resulting in small changes in total bryophyte richness (Hylander et al. 2005). Previous studies on bryophyte responses to clear-cutting in upland boreal habitats have considered short-term effects on small spatial scales, e.g., the $0.5-2 \mathrm{~m}^{2}$ plots used by Jalonen and VanhaMajamaa (2001) and Dovciak et al. (2006). In this study, we assessed relatively persistent effects of clear-cutting in large sample plots, making it possible to study also the less abundant species. Many forest bryophyte species have low abundance (Newmaster et al. 2005), presumably because they are associated with microhabitats with low cover.

It is difficult to predict whether upland or streamside forest would display higher resilience. Drier, warmer, and probably also lighter day-time conditions in upland pre-disturbance forests would make pre- and postdisturbance conditions more similar than in streamside areas potentially making uplands more resilient. On the other hand, microclimatic change is buffered in streamside forests by ample water supply (cool stream water and discharging groundwater, larger evaporation consuming heat, evaporated water readily replaced reducing desiccation) and the predominantly concave and thus wind-protected landscape setting (less desiccation). This would reduce pre/post-disturbance differences making streamside areas more resilient. Concerning gradients in resources and stress, high resource levels or low stress promote establishment, survival, growth and reproduction and thus raise both survival/recolonization (promoting resilience) and invasion by new species (reducing resilience). Thus, the cooler and moister microclimate in streamside than in upland clear-cuts may reduce the initial post harvest loss of bryophytes and promote subsequent recolonization by lost species, since bryophytes need moist conditions during establishment from diaspores. On the other hand, old streamside forests, that are generally cooler, moister and darker than old upland forests, should contain more bryophyte species intolerant of high temperatures, intense desiccation and radiation, and may thus lose more species.

Clear-cutting provides abundant opportunities for invasion by species that are competitively excluded by 


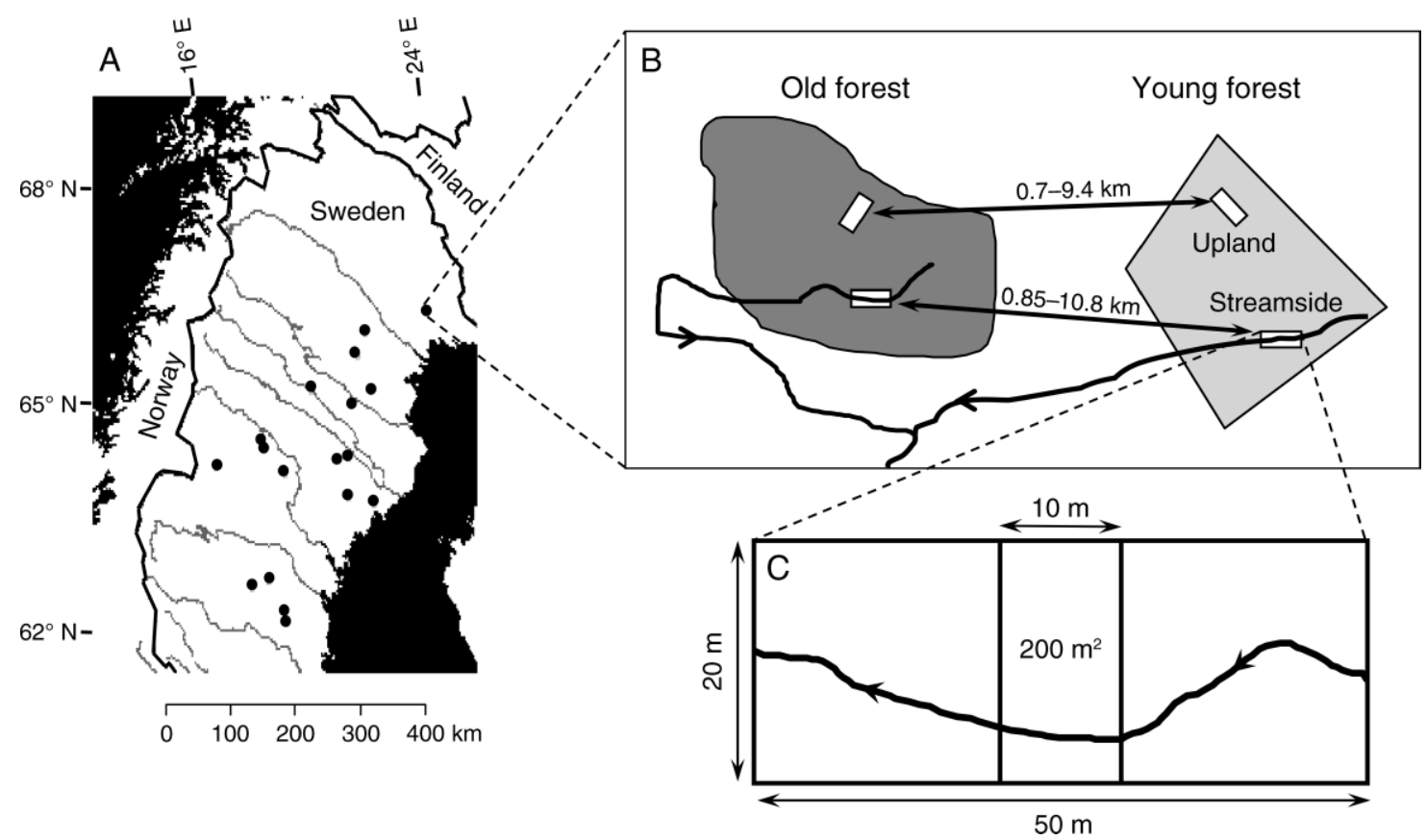

FIG. 1. (A) The location in northern Scandinavia of the 18 study sites. (B) A cluster of four 0.1-ha plots, two in streamside and two in upland areas, constituted a study site. Two of the plots were located in old stands that had never been clear-cut and two in young stands established after clear-cutting 30-50 years earlier. Arrows indicate the variation among sites in distance between the carefully matched old and young plots. (C) Top view of a streamside sampling plot with the stream and the central subplot indicated.

trees, understory vascular plants, and more competitive bryophytes in the old forest. Dynesius and Hylander (2007) found that a group of relatively short-lived species typical of open and disturbed habitats increased in richness and site occupancy shortly after clear-cutting of streamside forests, but returned to old-forest levels within 30-50 years. In the same study, we also found that some longer-lived and more competitive bryophyte species of open habitats still occupied streamside areas decades after clear-cutting. Upland sites, offering less favorable conditions for bryophyte establishment, are less likely to be invaded by new species (native or exotic) after disturbance and could thus be expected to have higher resilience than streamside sites in this respect.

This study provides the first comparison of resilience in streamside and upland sites. We specifically addressed the following questions:

1) Does resilience to clear-cutting in terms of species richness and composition of bryophyte assemblages differ between streamside and upland areas?

2) Is the resilience component survival/recolonization after clear-cutting higher in streamside areas?

3) Is the resilience component resistance to invasion by new species after clear-cutting lower in streamside areas?

In a paired design we compared bryophyte assemblages in forests that had never been clear-cut with assemblages in matching areas in young stands established after clear-cutting of old forests $30-50$ years earlier.
We considered small differences in bryophyte assemblages between disturbed and undisturbed stands to represent low degree of change, and therefore high resilience. For ease of reading, we frequently use terms describing response to clear-cutting in the presentation, although this is not entirely justified for a comparative study.

\section{Materials And Methods}

\section{Study area and plot selection}

The study area comprises northern Sweden between $62^{\circ} 08^{\prime}$ and $66^{\circ} 16^{\prime} \mathrm{N}$ (Fig. 1), situated within the Middle and North Boreal Zones (Ahti et al. 1968). Most of the region has been exposed to industrialized logging for about 150 years and clear-cutting has been the main mode of timber extraction since the 1950s.

Each of our 18 study sites included two pairs of 0.1-ha plots $(20 \times 50 \mathrm{~m})$, one pair in upland and one pair in streamside forest ( 4 plots $\times 18$ sites $=72$ plots; Fig. 1$)$. The plots within the pairs were matched to be as similar as possible except for forest history; one was in an old forest that had never been clear-cut and the other in a young stand 30-50 years after complete clear-cutting (see Plate 1). The streamside plots were along small streams with $0.2-2.8 \mathrm{~m}$ wide channels and a mean annual discharge of $1-68 \mathrm{~L} / \mathrm{s}$. The selection criteria for old streamside plots were (1) no anthropogenic drainage of the stream channel; (2) productive forest land, i.e., $\geq 1 \mathrm{~m}^{3}$ trunk volume (above stump height), including the bark, potentially produced per ha and year; (3) no nearby $(<50$ 
m) recent clear-cuts; (4) oldest trees were at least 150 years; and (5) the rectangular plot would fit longitudinally along the stream with the entire channel inside the plot. Criteria 2-4 were also used for upland plots. The old streamside and upland forest plots were located within $1 \mathrm{~km}$ of each other. We located similar stream and upland plots in the oldest clear-cuts of the landscape surrounding each old-forest site (Fig. 1). The matching of streamside plots involved catchment area, stream channel width, longitudinal and lateral slope, and amount of boulders and sediment. The matching of upland plots was made according to position in the landscape, amount of rock and boulders, and slope inclination.

\section{Habitat properties}

The 72 plots represented a large geographic area and wide ranges of habitat properties, allowing general conclusions from the results. The design, with geographically clustered plots and pairwise comparisons within clusters, eliminated most of the variation introduced by these wide ranges, which would otherwise confound the analyses.

The altitude ranged from 95 to $600 \mathrm{~m}$ above sea level and stream slope varied from almost level to steep. The soil type was mostly glacial till, sometimes partly covered by peat or sediments in streamside sites. Rocks and boulders were often abundant although mostly covered by organic material and understory vegetation. The surface area of downed logs available for wood-inhabiting bryophytes varied considerably; old forests of streamside sites had more log surface than old forests of upland sites, whereas the pattern was opposite in young stands. The mean site productivity of the upland plots (3.3 $\mathrm{m}^{3} \cdot \mathrm{ha}^{-1} \cdot \mathrm{yr}^{-1}$, trunk volume produced above stump height) compares well with the mean value for all productive forest land of the two northernmost counties of Sweden $\left(3.1 \mathrm{~m}^{3} \cdot \mathrm{ha}^{-1} \cdot \mathrm{yr}^{-1}\right.$; data from the Swedish National Forest Inventory), where the majority of the sites were situated. Soil moisture varied among upland plots (0-100\% of dry, mesic, and moist ground, respectively). The total basal area of trees in the old forests did not differ much between streamside and upland forests, but streamside stands had more Norway spruce (Picea abies) and birch (Betula spp.), whereas upland stands contained more Scots pine (Pinus sylvestris; see Plate 1). Twenty-two of the 36 old-forest plots had been subject to varying degrees of logging long ago, but had never been clear-cut. The mean and range of habitat properties among the different sites are found in Appendix A along with the methods used to collect the data.

\section{Differences in habitat properties between old and young forests}

Good matches between young and old stands were obtained, as illustrated by the small differences in most habitat properties (Appendix A). The only important exception was that rocks and boulders were more frequent in the old-forest plots, probably because abundant boulders hindered timber transport. All other differences are readily interpreted as changes caused by the clear-cutting, such as the slightly wetter soil conditions in the young forests (smaller biomass causing lower evapotranspiration), the change in tree species composition from the late successional Norway spruce to the pioneers Scots pine in upland sites and birch in streamside sites, and the lower amount of coarse woody debris (Appendix A). There had been virtually no input of coarse wood since the logging which is reflected in a low abundance of relatively undecomposed, coarse logs. Brushing and self-thinning produced some fine woody debris $(<10 \mathrm{~cm}$ in diameter), but this substrate is unsuitable for most wood-inhabiting bryophytes.

\section{Field survey of bryophytes}

The bryophyte data were collected during 1996-1997 (young stands) and 1998-2000 (old stands). The plots were analyzed at two scales: the entire 0.1 -ha plot and a subplot of $10 \times 20 \mathrm{~m}$ in the center of the large plot (Fig. 1). The subplot was investigated first, then the rest of the plot was examined for additional species. Since many bryophytes are substrate specific, the species lists were made by investigating all substrates and microhabitats until no new species were found. Thus, plots with higher micro-topographic or substrate heterogeneity required more time to analyze than more homogeneous plots. The time spent in young plots, however, was no less than the time spent in old plots. Taxonomy and nomenclature follows Hallingbäck et al. (2006). We collected difficult specimens, and identification was checked and, if necessary, corrected in the laboratory. The following combinations of species were, however, treated as one taxon each because they were often exceedingly difficult to distinguish in the field: the liverworts Cephalozia affinis + lunulifolia, Cephaloziella spp., Chiloscyphus pallescens + polyanthos, Leiocolea bantriensis + collaris + gillmanii, Pellia spp., and the mosses Sciuro-hypnum reflexum + starkei, Brachythecium rivulare + rutabulum, Dicranum flexicaule + fuscescens, Philonotis fontana + tomentella, Plagiothecium curvifolium + laetum, Rhizomnium magnifolium + pseudopunctatum, Sphagnum angustifolium + fallax, and Warnstorfia exannulata + fluitans.

\section{Ecological classification of species}

We separately analyzed subgroups of species classified according to their most common macrohabitat and substrate. We assigned each species to one of four types of macrohabitats following Hallingbäck (1996), and personal experience from the study area: forest, rocky outcrop, open mire, and river and road banks. Each species was assigned to one of 12 substrate groups (Table 1) in a similar manner as in Hylander and Dynesius (2006) and Dynesius and Hylander (2007). Species assigned to stream-channel substrates in these publications and that also appeared in upland stands in this study were assigned to their most frequent non- 
TABLE 1. Long-term responses to clear-cutting of bryophyte species richness in upland and streamside forests.

\begin{tabular}{|c|c|c|c|c|c|c|c|c|c|c|c|}
\hline \multirow[b]{2}{*}{ Species group } & \multicolumn{4}{|c|}{ Upland forests } & \multicolumn{4}{|c|}{ Streamside forests } & \multirow{2}{*}{$\frac{\text { All plots }}{P}$} & \multicolumn{2}{|c|}{$\begin{array}{l}\text { Difference } \\
\text { in response }\end{array}$} \\
\hline & $\begin{array}{c}\text { Change } \\
(\%) \dagger\end{array}$ & $\begin{array}{l}\text { Change in } \\
\text { mean no. }\end{array}$ & SE & $P$ & $\begin{array}{c}\text { Change } \\
(\%) \dagger\end{array}$ & $\begin{array}{l}\text { Change in } \\
\text { mean no. }\end{array}$ & SE & $P$ & & $P$ & $\% P$ \\
\hline All species & -26 & -10 & 1.1 & $<0.001$ & -6 & -4.8 & 3.4 & 0.157 & $<\mathbf{0 . 0 0 1}$ & 0.231 & $<\mathbf{0 . 0 0 1}$ \\
\hline Mosses & -21 & -5.1 & 0.80 & $<0.001$ & -1 & -0.56 & 2.3 & 0.698 & 0.009 & 0.107 & 0.004 \\
\hline Liverworts & -34 & -5.2 & 0.70 & $<0.001$ & -14 & -4.2 & 1.3 & 0.010 & $<\mathbf{0 . 0 0 1}$ & 0.711 & 0.004 \\
\hline Red-listed species $\ddagger$ & -100 & -0.17 & 0.090 & 0.083 & -54 & -0.39 & 0.22 & 0.088 & 0.025 & 0.357 & $\S$ \\
\hline \multicolumn{12}{|l|}{ By habitat affinity } \\
\hline Forest & -22 & -6.7 & 0.93 & $<\mathbf{0 . 0 0 1}$ & -8 & -4.2 & 1.8 & 0.042 & $<\mathbf{0 . 0 0 1}$ & 0.192 & 0.004 \\
\hline River and road banks & -43 & -0.83 & 0.59 & 0.221 & -6 & -0.50 & 1.1 & 0.569 & 0.187 & 0.909 & $\S$ \\
\hline Mires & -28 & -0.78 & 0.31 & 0.011 & +9 & +1.1 & 1.1 & 0.176 & 0.909 & 0.041 & $\S$ \\
\hline Rocky outcrops & -45 & -2.0 & 0.59 & 0.002 & -15 & -1.1 & 0.94 & 0.181 & 0.081 & 0.464 & $\S$ \\
\hline \multicolumn{12}{|l|}{ By substrate affinity\# } \\
\hline Downed logs & -57 & -2.2 & 0.41 & $<\mathbf{0 . 0 0 1}$ & -29 & -2.6 & 0.72 & 0.005 & $<\mathbf{0 . 0 0 1}$ & 0.584 & 0.007 \\
\hline Stumps & -22 & -1.6 & 0.27 & 0.001 & -11 & -0.83 & 0.26 & 0.009 & $<\mathbf{0 . 0 0 1}$ & 0.038 & 0.046 \\
\hline Boulders on land & -35 & -2.6 & 0.91 & 0.010 & -8 & -0.67 & 1.1 & 0.442 & 0.013 & 0.054 & 0.020 \\
\hline Boulders in stream & & & & & -6 & -0.22 & 0.86 & 0.813 & & & \\
\hline Dry to mesic ground & -12 & -0.94 & 0.42 & 0.029 & -11 & -0.78 & 0.58 & 0.206 & 0.020 & 0.795 & 0.795 \\
\hline Moist ground & -19 & -1.2 & 0.53 & 0.055 & +7 & +1.2 & 0.67 & 0.086 & 0.986 & 0.021 & 0.022 \\
\hline Wet ground & -19 & -0.17 & 0.33 & 0.571 & +7 & +0.61 & 0.92 & 0.314 & 0.482 & 0.407 & $\S$ \\
\hline $\begin{array}{l}\text { Stream channel } \\
\text { margin }\end{array}$ & & & & & -5 & -0.28 & 0.75 & 0.621 & & & \\
\hline $\begin{array}{l}\text { Living tree bases } \\
\text { and stems }\end{array}$ & -21 & -0.83 & 0.19 & 0.002 & -19 & -0.83 & 0.28 & 0.003 & $<\mathbf{0 . 0 0 1}$ & 0.768 & 0.773 \\
\hline Crevices & -27 & -0.17 & 0.19 & 0.366 & +12 & +0.44 & 0.52 & 0.452 & 0.810 & 0.376 & $\S$ \\
\hline Uprootings & -39 & -0.67 & 0.57 & 0.338 & -44 & -1.1 & 0.52 & 0.058 & 0.038 & 0.405 & $\S$ \\
\hline Dung or carcasses & +50 & +0.11 & 0.18 & 0.527 & +50 & +0.22 & 0.27 & 0.427 & 0.306 & 0.614 & $\S$ \\
\hline \multicolumn{12}{|l|}{ Shared species $\|$} \\
\hline Mosses & -29 & -5.4 & 0.64 & & -16 & -2.9 & 0.50 & & & 0.003 & \\
\hline Liverworts & -40 & -4.8 & 0.54 & & -28 & -3.3 & 0.33 & & & 0.014 & \\
\hline Forest species & -29 & -7.5 & 0.63 & & -17 & -4.5 & 0.47 & & & 0.002 & \\
\hline
\end{tabular}

Notes: The response is inferred from comparisons between matched 0.1-ha plots of old forests that have never been clear-cut and of young stands 30-50 years after clear-cutting. Each species was assigned to one habitat group and one substrate group. Differences in response between streamside and upland forests (last two columns) were analyzed for both change in absolute numbers and relative change $(\% P)$. All differences were analyzed using Wilcoxon's signed-rank test, and significant $P$ values are shown in boldface type (two-sided probability using normal approximation, $\alpha=0.05$ ). Standard error is given for the number of species. $N=18$ in all analyses except for "All plots" where $N=36$.

$\dagger$ Percentage change was calculated by dividing the change in total number of records in all plots taken together by the total number of records in all old-forest plots and then multiplying by 100 .

$\$$ Red-list status according to Gärdenfors et al. (2005). A total of 22 records of seven red-listed species were found, and two of these species were in the red list class "data deficient."

$\S$ These groups were not tested since they did not have species present in all 36 old-forest plots. No relative change could be calculated for these plots, because it is mathematically impossible to calculate a relative change using 0 as the starting point.

- Species for which the category is the most frequently occupied habitat in the landscape.

\# Species for which the category is the most frequently occupied substrate in old streamside forests.

Species present in both plots in a pair consisting of the old streamside plot and the old upland plot within a site. This analysis did not include any colonization of new species, and therefore the magnitude of the change should not be compared with that of the other groups.

stream substrate. All species put in the groups "stream channel margin" and "boulders in stream" were therefore found only in streamside stands. The macrohabitats and substrates assigned to each species are found in Appendix B.

\section{Data analysis}

To analyze changes in species richness in the entire assemblage as well as for subgroups, we made paired comparisons (pairs within sites) between old and young plots in upland and streamside forests separately (Table 1). We also analyzed differences between upland and streamside sites in the changes in species richness using a paired approach (the difference in species richness for each of the two plot pairs within a site was used as pairs). The latter analysis was made not only for absolute difference (number of species) but also for relative difference (percentage change from old to young). We analyzed the paired data using Wilcoxon's signed-rank test.

To assess differences in composition of bryophyte species between old and young stands (resilience) we used the multiresponse permutation procedure (MRPP; McCune and Mefford 1999). Monte Carlo permutation tests (with 1000 permutations) were used to statistically test for differences in composition. The analysis was done separately in upland and streamside sites. Since we did not collect data on abundance of individual species, 

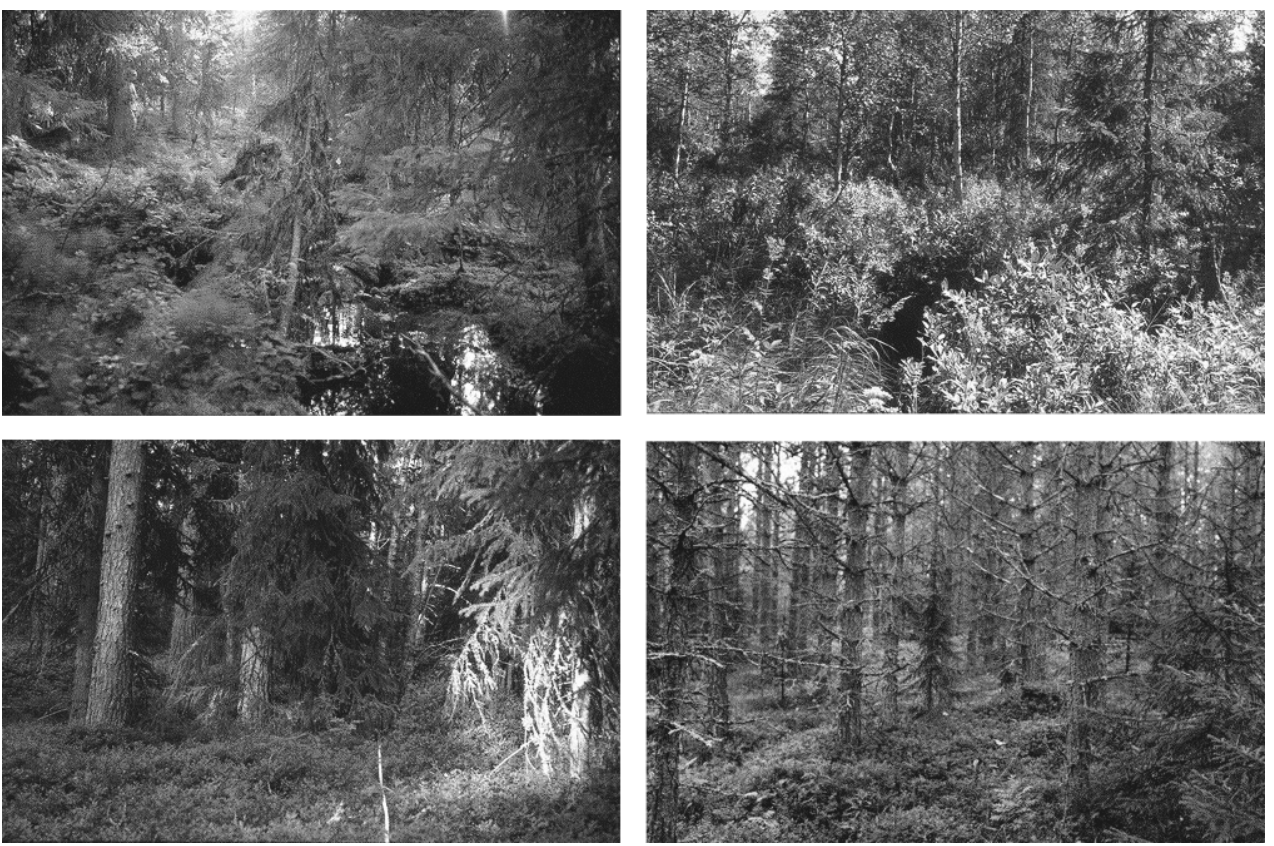

Plate 1. Examples of the four types of forests sampled in the study: old streamside (upper left), young streamside (upper right), old upland (lower left), and young upland (lower right). The study design was a space-for-time substitution, including 36 carefully matched pairs of old and young 0.1-ha plots, and two of these pairs are depicted here. Photo credits: M. Dynesius.

we used presence in the $10 \times 20 \mathrm{~m}$ subplot as an indicator of high abundance. Species present in the subplot were thus given an abundance of 2 whereas species absent from the subplot but present in the plot were given 1 . Because we wanted to use relative Sørensen distance, which is considered more appropriate for ecological data than Euclidean distance, we could not use blocked multiresponse permutation procedure MRBP, which should otherwise have been the natural choice with our paired design (McCune and Grace 2002).

To illustrate the variation in species composition we plotted site scores from a two-dimensional nonmetric multidimensional scaling ordination (NMS or NMDS). We used Sørensen distance and default settings (global NMS, a stability criterion of $0.005,10$ iterations with real data, maximum of 100 iterations) in PC-ORD version 4 (McCune and Mefford 1999).

To assess differences between upland and streamside sites in survival/recolonization and invasion we used three different approaches: survival/recolonization of shared species, species indicator values and changes in species site occupancy. To assess differences in survi$\mathrm{val} /$ recolonization we made pair-wise comparisons as described above but restricted them to species that were present in both the old streamside and the old upland plots in a site (shared species). In this way we reduced the influence of initial differences in species composition between streamside and upland forests.

In the second approach, we calculated species indicator values for young and old stands in upland and streamside forests separately, using the Dufrêne-
Legendre indicator species analysis in PC-ORD (McCune and Mefford 1999). If present in both streamside and upland forests, a species was assigned four indicator values from 0 to 100 , two for old and two for young stands. Input data were the same as in the MRPP analysis. By subtracting the species indicator value for old upland forest from the value for young upland forest, we got positive differences for species with an affinity to young upland forests and negative for species with an affinity for old upland forests. We compared the distribution of the differences in indicator values between upland and streamside sites using boxplots and tested for differences using the Mann-Whitney $U$ test for all the major bryophyte subgroups.

In the third approach, for upland and streamside forests separately, we counted the number of species that differed by two or more in the number of old vs. young stands occupied. Species present in at least two more young stands than old stands were termed "colonizing" species whereas those present in at least two more old stands than young stands were called "disappearing" species. The proportions of colonizing species in upland and streamside forests were compared and tested using a binomial test and the same was done for disappearing species. All analyses that were not done in PC-ORD were done using SYSTAT 11.00.01 (Systat Software 2004).

\section{Results}

\section{Overall responses to clear-cutting}

We recorded 269 species (92 liverworts and 177 mosses) in the 72 plots (7.2 ha) of young and old 


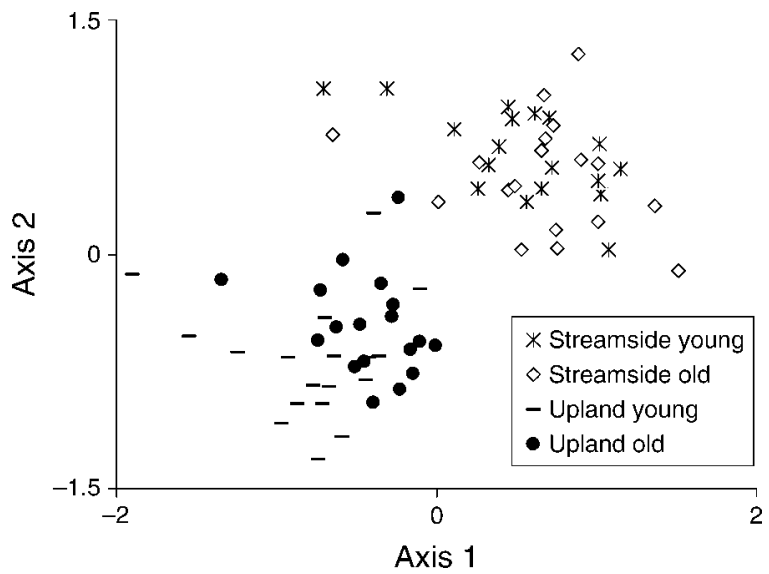

FIG. 2. Site scores from a two-dimensional nonmetric multidimensional scaling ordination (NMS) of the bryophyte flora in the 72 0.1-ha plots. We used Sørensen's distance measure.

upland and streamside forests (Appendix B). Compared to old forests, young clear-cut stands had fewer mosses, liverworts, red-listed species, forest species, and species growing most frequently on dry to mesic ground, boulders on land, woody substrates, bases and bark of living trees, and tree uprootings (Table 1). No group had significantly more species in young than in old forests. Species of woody substrates and of boulders were common among the species displaying the most evident negative responses to clear-cutting. Among the few species that had an affinity to young stands, one mire species (Aulacomnium palustre) and one boulder species (Andreaea rupestris) were prominent (Appendix C).

The species composition differed significantly between old and young sites in upland but not in streamside forests $(P \leq 0.00129[A=0.032]$ vs. $P=0.105[A=$ 0.006], MRPP [see McCune and Mefford 1999 for a description of the $A$ statistic]). This difference in response to disturbance is also revealed by NMS ordination, where the young and old upland plots were separated in ordination space, whereas the young and old streamside plots were not (Fig. 2).

\section{Changes in species richness in streamside and upland sites}

Lower species richness in young stands was found for twice as many bryophyte subgroups in upland compared to streamside forest. The reduction of species richness after harvest and initial stand development was generally larger in upland forests, both in absolute and relative terms (Fig. 3, Table 1). Thus, in upland areas clear-cutting reduced richness for most of the major subgroups and the largest proportional change was for species belonging to the downed logs substrate group, showing a richness reduction of more than half. Exceptions, which changed almost equally in upland and streamside forests, were the substrate subgroups dry to mesic ground, base and stem of living trees, tree uprootings, and dung and carcasses. The relative change was significantly different for most groups, whereas (because of lower richness in upland forests) absolute change was significantly different for only three groups: mire species, species of moist ground, and stump species (Table 1). Streamside forests had 13 records of five nationally red-listed species (Gärdenfors 2005) in old and six records of three such species in young stands, whereas upland forests had three records of one redlisted species in old and none in young forests.

\section{Survival/recolonization vs. invasion in streamside and upland sites}

The mean number of species shared between the old upland and the old streamside plots in a site was 30.7 (range 19-45, 12.1 liverworts and 18.6 mosses, $n=18$ plots), representing $76 \%$ of the mean number of species present in old upland forests. On average, 10.2 of these shared species were absent from the young upland plot compared to only 6.2 in the young streamside plot (Table 1, bottom rows), indicating a considerably higher survival/recolonization rate in streamside areas. The species in this group differing most in response were Sanionia uncinata (lost from seven more upland sites), Tetraphis pellucida (6), Pohlia cruda (5), Sphagnum girgensohnii (5), and Cephalozia affinis/lunulifolia (5). At the other end of the response spectrum was Dicranum polysetum (lost from five fewer upland sites).

Species' mean occupancy in old forest was almost identical in streamside and upland plots; $5.75(\mathrm{SE}=0.36$, $n=236)$ and $5.85(\mathrm{SE}=0.54, n=122)$ of the 18 plots. This similarity enables a comparison between upland and streamside forests of the changes in species' occupancy in response to clear-cutting. A higher proportion of the species in upland forest were classified as disappearing ( $37 \%$ vs. $25 \% ; P=0.012$, binomial test), whereas there were more colonizing species in streamside forests ( $15 \%$ vs. $1 \% ; P<0.001$, binomial test). In streamside forests, colonizing species constituted high proportions $(>20 \%)$ in the habitat subgroup open mires and in the substrate subgroups crevices, dung and carcasses, moist ground, and wet ground (Appendix D).

Based on differences between indicator values for young and old forests, species had a stronger association with old stands in upland compared to streamside forests in the following groups: liverworts, mosses, forest species and the three substrate subgroups boulders on land, tree bases and stems, and moist ground (Fig. 4). No group of species showed an opposite pattern, i.e., had a stronger association with old stands in streamside compared to upland forests. The differences in a species' indicator value for young and old stands ranged from -57 for the species with the strongest association with old uncut forests (the wood-inhabiting liverwort Cephalozia affinis/lunulifolia in upland areas) to +40 for the species having the strongest association with young stands (the boulder moss Andreaea rupestris in streamside areas). 

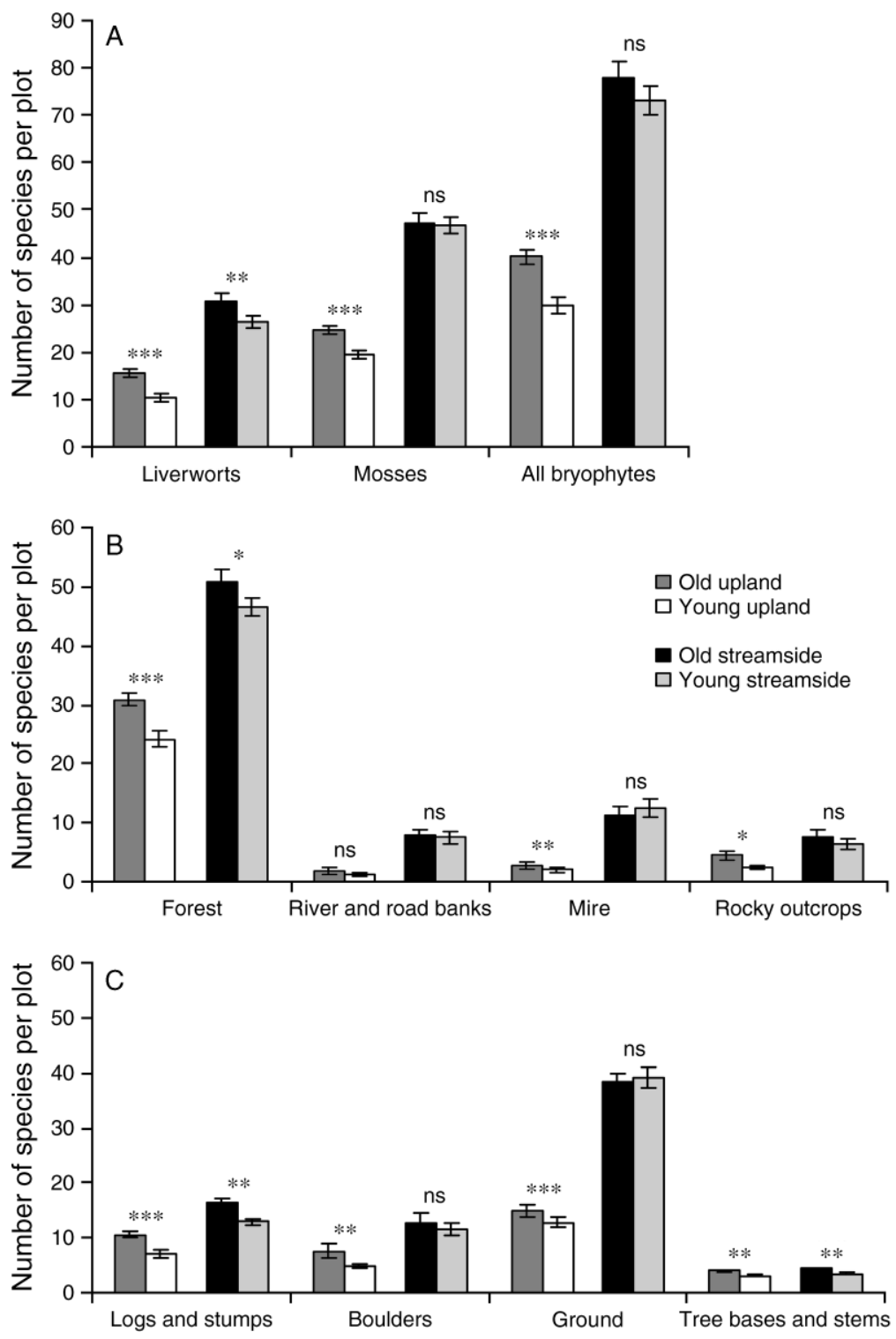

FIG. 3. Species richness of bryophyte groups in 0.1-ha plots. Each pair of bars compares old forests that have never been clearcut with matched young stands 30-50 years after clear-cutting. The comparison was made separately for upland and streamside stands. Subgroups shown are (A) phylogenetic groups, (B) groups based on species' main large-scale habitat, and (C) groups based on species' most frequent substrate in old streamside forests. For streamside forests, stream boulder species are included in "boulders" and stream-channel margin species in "ground" (see Table 1 for additional details and substrate groups). Error bars show \pm SE. Asterisks indicate pairs of bars where richness differs significantly between old and young stands (Wilcoxon's signedrank test: * $P \leq 0.05 ; * * P \leq 0.01 ; * * * P \leq 0.001 ;$ ns, $P>0.05)$.

\section{Discussion}

\section{Differences in resilience between streamside} and upland sites

Understanding the patterns and processes that govern biodiversity on various scales is a fundamental goal of ecology (e.g., Hubbell 2001) and a requirement for designing land use operations in a sustainable manner (e.g., Quetier et al. 2007, St-Laurent et al. 2008, but see Srivastava and Vellend 2005). The higher resilience of streamside assemblages (Fig. 2) was probably caused by better conditions for survival, reestablishment and growth of most bryophyte species. This result is in line with the higher resilience found for vascular plants in sites with low stress or high resource availability (Myerscough and Clarke 2007, Hamilton and Haeussler 2008, Slocum and Mendelssohn 2008).

The more pronounced species invasion somewhat reduced streamside resilience. A major cause of the higher invasion of streamside areas was most likely the 

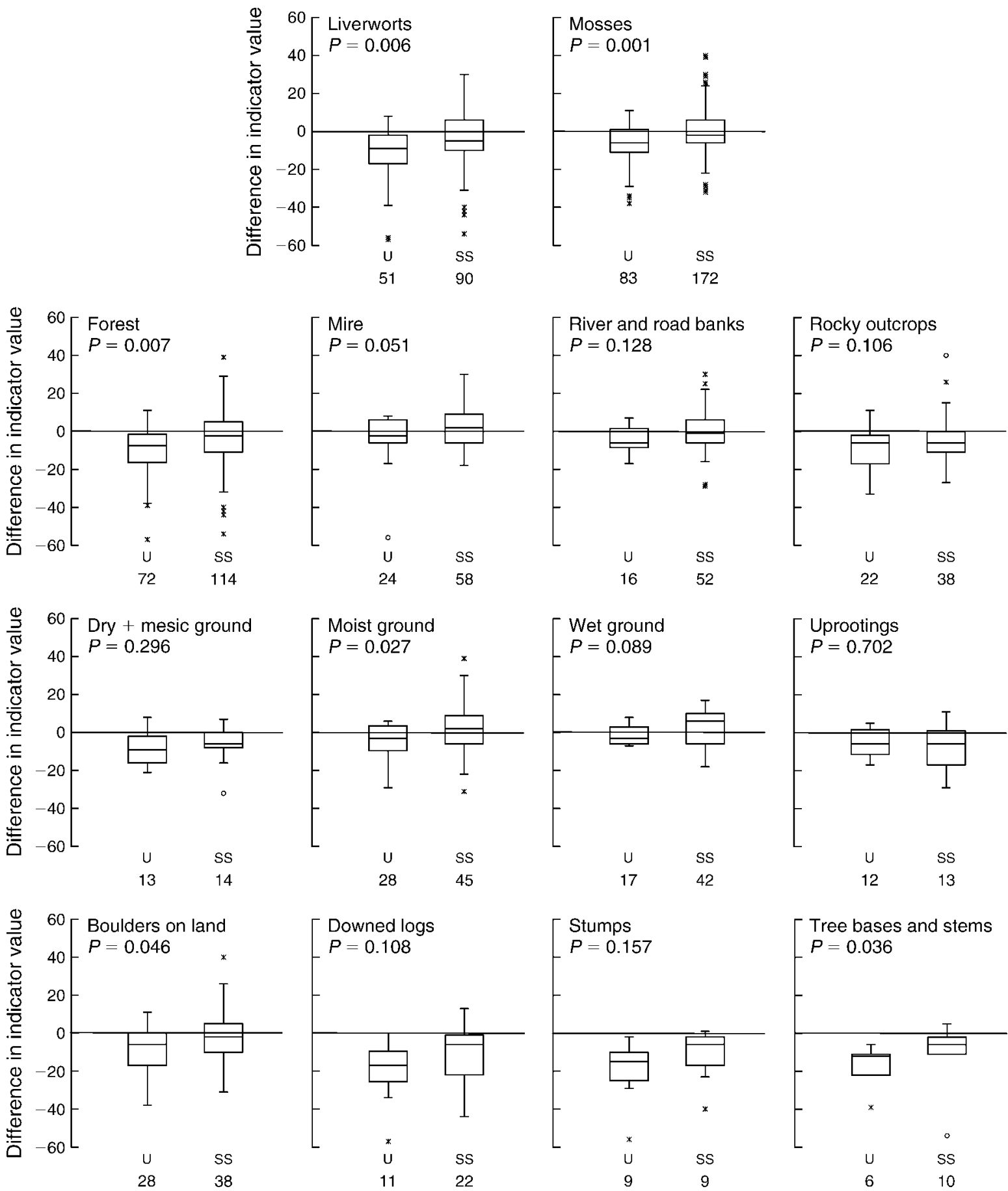

FIG. 4. Box plots illustrating the variation among species' long-term response to clear-cutting. The response variable is the difference between a species' indicator value for old and for young stands of a kind (upland or streamside), summarized for the number of species indicated below each box. Negative values denote species having higher indicator values for old than for young stands. Significance values are for differences between upland (U) and streamside (SS) forests and were derived from MannWhitney $U$ tests. Stream margin and stream boulder species were omitted (not present in upland forests). Crevice and dung or carcass groups were also excluded (low number of species). In each box plot, the center vertical line marks the median difference, the height of the box indicates the central $50 \%$ of the species, and whiskers indicate the range of observed differences that fall within 1.5 times the total box height away from the box; the species with differences falling outside the whiskers but within 3.0 times the total box height away from the box are plotted with asterisks, whereas species with even more extreme differences are plotted with open circles. 
better conditions for establishment and survival of most bryophyte species in streamside sites (cf. Kimmerer and Allen 1982), but additional factors probably contributed. A frequently overlooked factor in this type of study is the role of the character composition of the species pool. For example, very few, if any, bryophyte species in boreal Scandinavia are specialized to live on dry, sunexposed wood. Likewise, only a few species in our dataset are predominantly found on dry rocks and boulders, e.g., Racomitrium microcarpum, Andreaea rupestris, and Hedwigia ciliata, but these three species were already present in the old upland forests (Appendix B).

Most bryophyte species able to colonize the open, relatively dry boreal ground surface available after clearcutting of upland forests are short-lived and depend on soil disturbance (e.g., Ceratodon purpureus, Jungermannia caespiticia, Lophozia bicrenata, Pogonatum spp.). These species exhibit a marked abundance peak in the first years after clear-cutting (Dynesius and Hylander 2007), but in later stages, as those studied here, forest floor disturbance is scarce. In fact, such disturbance is usually less abundant and less continually provided than in old stands where individual tree uprootings may offer small-scale soil disturbance for decades by small-scale erosion of the tip-up mound (Jonsson and Esseen 1990). Composition of the species pool and patterns of forest floor disturbance were the probable causes for the fact that no species typical of open habitats or dry to mesic ground occupied considerably more young than old upland stands. Instead, several such species occupied a higher number of old stands (Fig. 4, Appendix D), and the richness of these groups was higher in old stands (Table 1). The landscape species pool contains, however, many long-lived species able to relatively persistently colonize the new, open, and moist habitats created by clear-cutting of streamside forests. The mire habitat group and the substrate groups wet and moist ground had more species associated with young than with old streamside forests (Fig. 4, Appendix D) and the richness of these groups tended be higher in young stands (Table 1). The lower resilience in streamside areas in terms of higher numbers of invading species is thus a result not only of better conditions for establishment, but also of the composition of the species pool present in the landscape.

The capacity of moisture to buffer microclimate appears to be pivotal to the survival/recolonization of bryophyte species. When considering the response of species present in both old upland and old streamside forests, clear-cutting led to a higher number of relatively persistent local extinctions when applied to uplands than to streamside areas (shared species of Table 1). Some species, however, did not survive/recolonize well in streamside areas (Appendix D) and they likely represented the least tolerant species regarding desiccation, high temperatures and high radiation intensities. Many of these species were also absent from old forests in uplands (Appendix B).

Local species extinctions were induced either by mechanical disturbance during forestry operations, altered microclimatic conditions exceeding the tolerance of species, or by changed competitive hierarchy. The high rates of local extinction found in short-term studies suggest that direct, almost immediate, processes dominate over indirect slower processes such as competition (e.g., Nelson and Halpern 2005, Dynesius and Hylander 2007). The higher resilience in streamside forests may, however, not exclusively relate to conditions for initial survival but also to a more rapid reestablishment. In addition to being inherently moister, streamside areas had a faster establishment of sheltering woody vegetation that may have facilitated recolonization by stabilizing near-ground moisture. Compared to old-forest conditions, tree cover in young streamside stands decreased less and shrub cover increased more than in upland sites (Appendix A).

Substrate abundance and microclimate may interact to determine the presence or absence of bryophyte species. The lower cover of boulders in young than in old stands (Appendix A) led to a lower number of boulder species only in young upland forests (Fig. 3), although the difference in boulder cover between old and young stands was larger in streamside areas (Appendix A). Higher moisture and/or shelter apparently protected some boulder species from local extinction in streamside areas. Instead, a number of boulder species had a stronger association with young than with old streamside forests (Fig. 4, Appendices C and D) probably as a response to increased light availability. Other examples of interactions between microclimate and substrate are found among wood-inhabiting species. Despite the obvious increase in the amount of stumps, none of the nine species in the stump substrate group occupied a higher number of young than old stands. Instead, seven of them occupied fewer stands (Appendix B). The same pattern was found for species mainly growing on downed logs: although young upland stands had $\sim 50 \%$ larger log surface area than young streamside stands (Appendix A), they had $\sim 70 \%$ fewer log species per plot and log species tended to be more strongly associated with old forests in upland areas (Fig. 4). Species growing on convex substrates such as boulders and dead wood are especially sensitive to differences in air moisture (e.g., Hylander et al. 2005) and this probably contributes considerably to the higher resilience of streamside bryophyte assemblages.

\section{Ecological resilience}

Differences in ecological resilience (sensu Holling [1996]; i.e., the amount of disturbance a system can absorb without irreversible change) between upland and streamside communities are difficult to establish because of the long time spans involved in forest succession (Schröder et al. 2005, Hamilton and Haeussler 2008). 
Although our data show that engineering resilience to clear-cutting (the inverse of return time, here measured as similarity to pre-disturbance assemblages after a specific time) was lower in upland than in streamside areas, we hypothesize that ecological resilience is lower in streamside areas. Both the better conditions for species invasion and the presumed higher number of highly disturbance-intolerant mature forest species may cause lower ecological resilience in streamside areas. For example, with a more severe disturbance than the clearcutting practice employed here, even more species would invade streamside areas, potentially leading to permanent state shifts by excluding original members of the assemblage (cf. Hobbs and Huenneke 1992). In the present study system, the strong reduction in species numbers in upland forests almost half-way into the forestry rotation period indicates that some species, especially those growing on convex substrates such as decomposing wood and boulders, may not be able to recolonize before the next stand-replacing cutting. Since boreal forests will probably continue to be exposed to clear-cutting forestry with relatively short rotations, the species composition of bryophytes in upland forests may be permanently changed at a local scale. If not exposed to recurrent clear-cutting, however, we expect bryophyte assemblages of upland forests to return to their original states, i.e., to have high ecological resilience. This expectation stems from the assumption that almost all species present in pre-disturbance upland forests are still frequently present in the landscape after large-scale clear-cutting (for example in streamside clear-cuts as shown in the analysis of shared species, Table 1), whereas many streamside old-forest species, being the species most intolerant to canopy disturbance, become rare or extinct over large areas. In such a scenario, clearcut streamside forests that are set aside to develop freely might not fully recover because recruitment by dispersal is hindered by habitat loss and fragmentation (Starzomski and Srivastava 2007).

The uncertainty about differences in ecological resilience between streamside and upland areas calls for further studies and shows that a general understanding of how components of resilience relate to gradients in stress and resources across landscapes is still far ahead (Gilad et al. 2007). It also suggests that high engineering resilience may not necessarily be associated with high ecological resilience, contradicting the prediction by van Nes and Scheffer (2007).

To conclude, our results indicate that resilience is affected by gradients in stress and resource availability causing gradients in both survival/recolonization and invasion rates. To further complicate the relationship, the proportion of disturbance-intolerant species may vary spatially as may the magnitude of change in environmental conditions caused by a constant disturbance. These general statements are likely valid not only for forest bryophytes, but for many ecosystems and organism groups (cf. Halpern 1988). Bryophytes are, however, useful for studies of these relationships in forests since they include a relatively high proportion of late successional species that are intolerant of canopy disturbance (Fenton and Frego 2005).

\section{Landscape-scale resilience}

The results of this study add to those of our comparison of north- and south-facing slopes concerning short-term resilience of bryophyte assemblages to clear-cutting (Åström et al. 2007). Bryophyte assemblages on north-facing slopes, like those in streamside areas, were more resilient, lost fewer species and were invaded by a higher number of species compared to assemblages on south-facing slopes. The emerging picture is one of topography causing a wide range in resilience of bryophyte communities across the boreal forest landscape (but, as previously suggested, not necessarily correlated with ecological resilience). High bryophyte resilience through high survival/recolonization rate is found in settings where topography is concentrating water (concave settings: this study and Hylander et al. 2005) or reduces solar radiation (e.g., north-facing slopes).

Expanding from this, we hypothesize that, for many groups of forest organisms that include species with difficulties to cope with the environment on clear-cuts, a topographically heterogeneous landscape (variable exposition) with high stream density (high proportion of streamside forest) will have higher landscape-scale resilience to clear-cutting forestry and other disturbances than a more level landscape poor in streams. On a smaller scale, microtopographically heterogeneous ground (e.g., caused by boulders) may also provide higher resilience compared to level, homogeneous ground, but this more generalized conjecture requires testing. The rationale for these hypotheses is that topographically heterogeneous areas have a wider range of climatic and other conditions (cf. Chapin et al. 2004), increasing the probability that at least some individuals of a species find themselves in locations that remain tolerable through a disturbance event. Assuming this survival of subpopulations, dispersal distances to new, previously intolerable sites that have become suitable after disturbance will also be shorter.

Higher resilience of bryophyte and other communities in parts of the landscape does not mean that clearcutting should be directed primarily towards these sites. Old streamside forests contain many of the bryophyte species that are most intolerant of clear-cutting, and many of these species had still not recolonized 30-50 years after disturbance (Dynesius and Hylander 2007). It should be possible to further strengthen the capacity of high-resilience areas to function as life boats for forestry-intolerant species (e.g., by avoiding logging close to streams), thereby enhancing resilience at a larger spatial scale (cf. Bengtsson et al. 2003, Tscharntke et al. 2005). 


\section{ACKNOWLEDGments}

We thank N. Lönnell for inventorying bryophytes in young stands, A. S. Duerden and B. G. Jonsson for determining liverworts from young forests, K. Damsholt and L. Hedenäs for checking some of our difficult specimens, and E. Carlborg, M. Danvind, A. S. Duerden, A. Löfgren, M. Svedmark, and U. Zinko for assistance in establishing plots and in collecting environmental data. We thank S. Haeussler, R. Jansson, B. G. Jonsson, R. E. Ricklefs, and an anonymous reviewer for valuable comments on the manuscript. We are grateful to the County Administrations of northern Sweden which kindly permitted us to work in nature reserves. The work was made possible by grants from the former Swedish Council for Forestry and Agricultural Research (to C. Nilsson), the Kempe Foundations, the Royal Swedish Academy of Sciences (HiertaRetzius Fund), and Ruth and Gunnar Björkman's Fund for Botanical Research in Norrland (all to M. Dynesius).

\section{Literature Cited}

Ahti, T., L. Hämet-Ahti, and J. Jalas. 1968. Vegetation zones and their sections in northwestern Europe. Annales Botanici Fennici 5:169-211.

Arnan, X., A. Rodrigo, and J. Retana. 2006. Post-fire recovery of Mediterranean ground ant communities follows vegetation and dryness gradients. Journal of Biogeography 33:12461258.

Åström, M., M. Dynesius, K. Hylander, and C. Nilsson. 2007. Slope aspect modifies community responses to clear-cutting in boreal forests. Ecology 88:749-758.

Bengtsson, J., P. Angelstam, T. Elmqvist, U. Emanuelsson, C. Folke, M. Ihse, F. Moberg, and M. Nyström. 2003. Reserves, resilience and dynamic landscapes. Ambio 32:389-396.

Berglund, H., and B. Jonsson. 2001. Predictability of plant and fungal species richness of old-growth boreal forest islands. Journal of Vegetation Science 12:857-866.

Boose, E., D. Foster, and M. Fluet. 1994. Hurricane impacts to tropical and temperate forest landscapes. Ecological Monographs 64:369-400.

Chapin, F. S., III, et al. 2004. Resilience and vulnerability of northern regions to social and environmental change. Ambio 33:344-349.

Clausen, E. 1952. Hepatics and humidity: a study of the occurrence of hepatics in a Danish tract and the influence of relative humidity on their distribution. Dansk Botanisk Arkiv 15:1-80.

DeAngelis, D. L. 1991. Dynamics of nutrient cycling and food webs. Chapman and Hall, London, UK.

Dovciak, M., C. B. Halpern, J. F. Saracco, S. A. Evans, and D. A. Liguori. 2006. Persistence of ground-layer bryophytes in a structural retention experiment: initial effects of level and pattern of overstory retention. Canadian Journal of Forest Research 36:3039-3052.

Dynesius, M., and K. Hylander. 2007. Resilience of bryophyte communities to clear-cutting of boreal stream-side forests. Biological Conservation 135:423-434.

Dynesius, M., and U. Zinko. 2006. Species richness correlations among primary producers in boreal forests. Diversity and Distributions 12:703-713.

Esseen, P. A., B. Ehnström, L. Ericson, and K. Sjöberg. 1997. Boreal forests. Ecological Bulletins 46:16-47.

Fenton, N. J., and K. A. Frego. 2005. Bryophyte (moss and liverwort) conservation under remnant canopy in managed forests. Biological Conservation 122:417-430.

Frego, K. 2007. Bryophytes as potential indicators of forest integrity. Forest Ecology and Management 242:65-75.

Frisvoll, A. A. 1997. Bryophytes of spruce forest stands in Central Norway. Lindbergia 22:83-97.

Gärdenfors, U., editor. 2005. The 2005 red list of Swedish species. Swedish Species Information Centre, Uppsala, Sweden.
Gilad, E., J. von Hardenberg, A. Provenzale, M. Shachak, and E. Meron. 2007. A mathematical model of plants as ecosystem engineers. Journal of Theoretical Biology 244: 680-691.

Gunderson, L. H. 2000. Ecological resilience, in theory and application. Annual Review of Ecology and Systematics 31: 425-439.

Hallingbäck, T. 1996. Ekologisk katalog över mossor. [The bryophytes of Sweden and their ecology.] Swedish Species Information Centre, Uppsala, Sweden.

Hallingbäck, T., L. Hedenäs, and H. Weibull. 2006. New checklist of Swedish bryophytes. Svensk Botanisk Tidskrift 100:96-148.

Halpern, C. B. 1988. Early successional pathways and the resistance and resilience of forest communities. Ecology 69: $1703-1715$.

Hamilton, E. H., and S. Haeussler. 2008. Modeling stability and resilience after slashburning across a sub-boreal to subalpine forest gradient in British Columbia. Canadian Journal of Forest Research 38:304-316.

Hobbs, R. J., and L. F. Huenneke. 1992. Disturbance, diversity, and invasion: implications for conservation. Conservation Biology 6:324-337.

Holling, C. S. 1973. Resilience and stability of ecological systems. Annual Review of Ecology and Systematics 4:1-23.

Holling, C. S. 1996. Engineering versus ecological resilience. Pages $31-43$ in P. C. Schulze, editor. Engineering within ecological constraints. National Academy Press, Washington, D.C., USA.

Hubbell, S. P. 2001. The unified neutral theory of biodiversity and biogeography. Princeton University Press, Princeton, New Jersey, USA.

Hylander, K., and M. Dynesius. 2006. Causes of the large variation in bryophyte species richness and composition among boreal streamside forests. Journal of Vegetation Science 17:333-346.

Hylander, K., M. Dynesius, B. G. Jonsson, and C. Nilsson. 2005. Substrate form determines the fate of bryophytes in riparian buffer strips. Ecological Applications 15:674-688.

Jalonen, J., and I. Vanha-Majamaa. 2001. Immediate effects of four different felling methods on mature boreal spruce forest understorey vegetation in southern Finland. Forest Ecology and Management 146:25-34.

Jonsson, B. G., and P. A. Esseen. 1990. Treefall disturbance maintains high bryophyte diversity in a boreal spruce forest. Journal of Ecology 78:924-936.

Kimmerer, R. W., and T. F. H. Allen. 1982. The role of disturbance in the pattern of a riparian bryophyte community. American Midland Naturalist 107:370-383.

McCune, B., and J. B. Grace. 2002. Analysis of ecological communities. MjM Software Design, Gleneden Beach, Oregon, USA.

McCune, B., and M. J. Mefford. 1999. PC-ORD. Multivariate analysis of ecological data. MjM Software Design, Gleneden Beach, Oregon, USA.

Mills, S., and S. Macdonald. 2004. Predictors of moss and liverwort species diversity of microsites in conifer-dominated boreal forest. Journal of Vegetation Science 15:189-198.

Moritz, M. 1997. Analyzing extreme disturbance events: fire in Los Padres National Forest. Ecological Applications 7:12521262.

Myerscough, P. J., and P. J. Clarke. 2007. Burnt to blazes: landscape fires, resilience and habitat interaction in frequently burnt coastal heath. Australian Journal of Botany 55:91-102.

Nelson, C., and C. Halpern. 2005. Short-term effects of timber harvest and forest edges on ground-layer mosses and liverworts. Canadian Journal of Botany 83:610-620.

Newmaster, S., and F. Bell. 2002. The effects of silvicultural disturbances on cryptogam diversity in the boreal-mixedwood forest. Canadian Journal of Forest Research 32:38-51. 
Newmaster, S., R. Belland, A. Arsenault, D. Vitt, and T. Stephens. 2005. The ones we left behind: comparing plot sampling and floristic habitat sampling for estimating bryophyte diversity. Diversity and Distributions 11:57-72.

Odum, H. T., and R. C. Pinkerton. 1955. Time's speed regulator: the optimum efficiency for maximum power output in physical and biological systems. American Scientist 43:331-343.

O'Neill, R. V. 1976. Ecosystem persistence and heterotrophic regulation. Ecology 57:1244-1253.

Proctor, M. C. F. 1990. The physiological basis of bryophyte production. Botanical Journal of the Linnean Society 104: 61-77.

Quetier, F., S. Lavorel, W. Thuiller, and I. Davies. 2007. Planttrait-based modeling assessment of ecosystem-service sensitivity to land-use change. Ecological Applications 17:23772386.

Rydgren, K., R. Økland, and G. Hestmark. 2004. Disturbance severity and community resilience in a boreal forest. Ecology 85:1906-1915.

Sarr, D. A., and D. E. Hibbs. 2007. Multiscale controls on woody plant diversity in western Oregon riparian forests. Ecological Monographs 77:179-201.

Schröder, A., L. Persson, and A. M. De Roos. 2005. Direct experimental evidence for alternative stable states: a review. Oikos 110:3-19.
Slocum, M. G., and I. A. Mendelssohn. 2008. Use of experimental disturbances to assess resilience along a known stress gradient. Ecological Indicators 8:181-190.

Srivastava, D. S., and M. Vellend. 2005. Biodiversity-ecosystem function research: Is it relevant to conservation? Annual Review of Ecology, Evolution and Systematics 36:267-294.

Starzomski, B. M., and D. S. Srivastava. 2007. Landscape geometry determines community response to disturbance. Oikos 116:690-699.

St-Laurent, M.-H., J. Ferron, S. Haché, and R. Gagnon. 2008. Planning timber harvest of residual forest stands without compromising bird and small mammal communities in boreal landscapes. Forest Ecology and Management 254:261-275.

Systat Software. 2004. SYSTAT 11.00.01. Cranes Software International, Bangalore, India.

Tscharntke, T., A. M. Klein, A. Kruess, I. Steffan-Dewenter, and C. Thies. 2005. Landscape perspectives on agricultural intensification and biodiversity: ecosystem service management. Ecology Letters 8:857-874.

Turner, M. 2005. Landscape ecology: what is the state of the science? Annual Review of Ecology, Evolution, and Systematics 36:319-344.

van Nes, E. H., and M. Scheffer. 2007. Slow recovery from perturbations as a generic indicator of a nearby catastrophic shift. American Naturalist 169:738-747.

White, P. S., and A. Jentsch. 2001. The search for generality in studies of disturbance and ecosystem dynamics. Progress in Botany 62:399-450.

\section{APPENDIX A}

A table of the means and ranges of habitat properties for the four types of stands studied: old and young streamside and upland stands (Ecological Archives E090-067-A1).

\section{APPENDIX B}

A list of all 269 taxa recorded including information on their red-list status, main macrohabitat and substrate affiliation, and their plot occupancy in the four types of stands studied (Ecological Archives E090-067-A2).

\section{APPENDIX C}

A list of the 16 taxa that differed most distinctively in occupancy between old and young stands, including information on their main macrohabitat and substrate and their occupancy in the four stand types (Ecological Archives E090-067-A3).

\section{APPENDIX D}

A table with the accumulated number of taxa found in all upland and all streamside plots for different bryophyte groups, and the number and proportion of these species that were classified as disappearing or colonizing (Ecological Archives E090-067-A4). 